\title{
Archæological Studies in Great Britain
}

$A^{N}$ outstanding feature of the first International A Congress of Prehistoric and Protohistoric Sciences held in London last week was afforded by the group of lectures which were delivered at the general meet ings of the Congress held on the evenings of Aug. 2, 3, and 5, and on the morning of Aug. 6, to which the presidential address on the afternoon of Aug. I, and the exhibition of British archæology in the field at the London Museum, to which reference was made in NATURE of Aug. 6, p. 196, had formed an appropriate introduction. While Sir Charles Peers, in his address on "The Beginnings of British Archeology", had traced the stages by which interest in the exploration of the past had attained the status of a scientific study, and the exhibition had given a practical demonstra tion of what is now being achieved in the field, Dr. Cyril Fox, Mr. E. T. Leeds, and Mr. T. D. Kendrick laid before their audiences the results of synthetic study of the facts most lately won in the field at three strategic points in the early history of the British Isles. The picture was completed on the morning of Aug. 6 by Mr. O. G. S. Crawford's account of Britain's achievement in the development of archæological discovery by photography from the air, which was so admirably illustrated by the photographs exhibited by the Ordnance Survey at the London Museum.

Sir Charles Peers, in his presidential address, while tracing the spirit of the archæologist back to the interest of primitive man in his predecessors, distinguished the latter as a hope for treasure, while around the great monuments of the past, which have never failed to arouse the attention of the living, has collected a mass of material, sometimes dignified by the name of folk-lore, which should not be overlooked. Early antiquaries explained prehistory in the light of history as known to them. When anything remarkable remained, the natural tendency was to ascribe it to the Romans. Camden, the learned forerunner of modern antiquaries, saw no reason to ascribe a date before the Roman occupation of Britain to any notable monument except Stonehenge-insana substructio. Aubrey, the Wiltshire squire, said Sir Charles, had the definite merit of setting down what he saw. In 1648 he was impressed by the absurdity of deriving such structures as Avebury from the classical tradition. $\mathrm{He}$ was persuaded that Stonehenge was a temple of the Druids. Then came William Stukely, a man gifted with a vivid imagination and an insatiable curiosity. "What is all learning ", he said, "but a knowledge of antiquities?" Sir Charles then reviewed the work of Sir Richard Colt Hoare, whose book on the Wiltshire monuments, of which the first volume was published in 1810, was prefaced with the words, "we speak from facts not theory"; of William Smith, whose geological map of England demonstrated a succession of ruined worlds, opening the way to a new conception of the prehistory of man; and of John Frere, who attributed his palæolithic implements to a period " even beyond the present world "-the transition from ancient to modern archæology.

Dr. Cyril Fox, in his address on "The Personality of Britain ", dealt with some of the fundamental principles of prehistory, demonstrating the bearing of climate and soil, and the resulting vegetable and animal life, on man and his history. As a whole, these represent man's environment and Britain's personality. The position of Britain, he said, adjacent to five hundred miles of European coast, renders the country liable to invasion, while its indented outline is convenient for invaders, and its estuaries and slowmoving rivers invite penetration. Of the three main routes for invaders, the western coast, the English Channel, or the Straits of Dover, and the North Sea, that by the Straits of Dover, was not open or was a narrow gorge, when, in early times, the land was higher ; but when subsidence and erosion had moulded Britain to its now familiar form, invasion tended to concentrate on Kent and the Thames estuary.

Dr. Fox then proceeded to show how the structural division of the island of Britain south of the Forth. Clyde isthmus into a western highland zone and an eastern lowland zone led to the imposition of cultures on the east, which was easily overrun by invaders, while in the highland zone they were absorbed. In the same way the fertile lowlands nourished wealthier populations, while north of the Forth-Clyde isthmus the Highlands tended to develop unique cultures. Influences from Ireland were usually limited to the highland zone. The lands washed by the Irish Sea thus tended to develop cultural unity. In the same way, soil was the controlling factor in lowland distribution and elevation in the highland, as man could not stand the cold. The most complete manifestation of any primitive culture entering eastern or southern Britain from the Continent focused in the Salisbury Plain region, but as civilisation developed, overseas trade moved in the direction of the Thames estuary and a change came in the type of soil and country desired by the inhabitants. Hence the progress from subjection to environment to control of environment, from barbarism to civilisation, is expressed by the utilisation of oak forests and the substitution of arable fields.

In "Celtic Art in Britain", Mr. E. T. Leeds sought to trace the origins and development of an artistic epoch which lasted from its beginnings in La Tène style down to the eleventh century of our era. It was first implanted on the south coast, probably in the late fifth or fourth century B.C., and taking root firmly in the third century B.C., when it began to discard the naturalistic tendencies of the parent continental school in favour of geometrical arrangements of curving lines. This school found its most brilliant expression in a western school, the districts first occupied by iron age peoples, which permeated the eastern Midlands and spread to Yorkshire and beyond. A period of decadence ensued. While intruding Belgic tribes developed champlevé enamelling, the British craftsman attempted novel designs by "breaking the back of the curve".

Before the Roman conquest, southern Britain was falling under the influence of continental mass production. There is a loss of originality and an increase of formalism. Small geometrical designs in enamel aim at a jewelled effect : on the periphery of the Roman occupation, however, Celtic art survived and the Celtic genius adapted classical models as in the Asica brooch. A fresh burst of activity set in as seen in the enamelled escutcheons of the Winchester and other bowls, a group confined to the east of the Fosse Way. The outcome was the trumpet scrolls beloved of the Celt with his feeling for the curving line. This renaissance in southern England in the sixth and seventh centuries, in conjunction with certain zoomorphic designs, provides the key to the sudden appearance in Ireland at the close of the seventh century of such masterpieces as the Book of Durrow, unheralded by anything in the previous art history of the island.

Mr. T. D. Kendrick, in "The Crafts in Ancient Britain ", dealt with the difficult but none the less interesting period of the Early Dark Ages, holding 
out the hope that it may soon be possible for the archæologist to discern the long awaited Arthurian archæology of Britain. Though Vortigern, Aurelius Ambrosianus, and King Arthur mean much to the historian, archæologically they and their subjects are almost unknown. The lost archæology of the Briton has to be reconstructed from material found in the graves of his conquerors. Investigation of the chronological position of such material as the famous 'Kingston' brooch shows that it is more likely to be British than Jutish, as it has been regarded. There is a definite probability of some progress in the task of sorting out minor Arthurian antiquities from the 'Anglo-Saxon' cases of the museums.

\section{Rimu or New Zealand Red-Pine}

$I^{\mathrm{N}}$ view of the fact that the possibility of obtaining supplies of soft woods from the Empire is so much in the forefront at the present day, a leaflet by W. C. Ward on the "Properties and Uses of Rimu" (N.Z. For. Service, Leaflet, No. 17, Nov. 1931) merits consideration. The author states that rimu (Dacry. dium cupressinum) supplies rank as the most important soft wood in New Zealand. It is milled and marketed in every timber-producing district in the country, and is the principal building timber in the Dominion. It is employed in almost every local woodusing industry, and in many is the chief timber used. At the present time, practically the whole of the rimu produced is consumed locally, less than 3 per cent being exported. The quantity milled annually exceeds that of all other species combined, and during the year ending March 31, 1930, totalled 159,000,000 ft. Board Measure (B.M.), or 58 per cent of the total timber production of the Dominion. In 1920-1930 the annual cut of the species exceeded 140,000,000 ft. B.M., the peak production of $195,000,000 \mathrm{ft}$. B.M. in 1926 representing 55 per cent of the total timber produced that year. That the fellings are exceeding the annual increment or possibility is exemplified by the statement that a few years ago Auckland supplied a far larger proportion of the total cut than any of the other districts, but its accessible supplies have now dwindled, and Westland has taken the lead and is said to be likely to supply an increasing percentage in future years.

The first detailed statistics on the export of rimu were collected in 1913 , when $8,500,000 \mathrm{ft}$. B.M. were exported. In the War years the trade increased, and by 1918 the total exports had reached $30,000,000 \mathrm{ft}$. B.M. This was due to the difficulty in obtaining supplies of North American and Scandinavian timber during the War years. With the drop in price of the foreign species at the end of the War, and low ocean freights, it was possible to land the foreign material cheaper in Australia than rimu. The exports of the latter to Australia had fallen to $4,000,000 \mathrm{ft}$. B.M. in
1925, and have remained at that figure ever since. Recent customs duties on foreign timber in Australia now permit rimu to compete successfully once more, and a recent survey has shown that $20,000,000 \mathrm{ft}$. B.M. of rimu could be used in Australia annually.

The leaflet is written from the marketing and manufacturing point of view. It is to be hoped that the Forest Department will bear in mind the great value to the country of this fine timber, and will take steps to see that its regeneration is undertaken, in order to perpetuate supplies.

The rimu is a fine forest tree, the height in the average commercial stand varying from $60 \mathrm{ft}$. to $120 \mathrm{ft}$. When mature, its trunk is long, straight, unbranched, and with little taper, carrying a compara. tively open and irregular crown. From the remarkable weeping habit of its foliage it is the most easily recognised and best known of all New Zealand trees. The commercial bole usually varies from $40 \mathrm{ft}$. to $80 \mathrm{ft}$. in length. Its diameter, breast height, in mature stands varies from $2 \mathrm{ft}$. to $4 \mathrm{ft}$., although it is said that many of the trees at present converted range below the lower limit. In other words, as is invariably the case when primeval forests are lumbered, immature trees are being felled along with the mature ones. Occasionally trees up to $8 \mathrm{ft}$. diameter are encountered and milled. It might be suggested that a few stands of these fine old trees should be selected by Government and reserved to show future generations what the New Zealand soil is capable of producing.

Although the tree grows on flat, but not marshy, land, it favours undulating localities and hillsides, being found at all altitudes from sea-level up to $2500 \mathrm{ft}$. With the exception of the pure beech (Nothofagus) stands, rimu occurs in every major type of forest growth, and in the North Island it is an occasional associate of the kauri.

Mr. Ward gives interesting details on manufacture, seasoning, grading, the properties of the wood and durability, and adds notes on its utilisation by various industries.

\section{Winter Climate of Greenland}

TN a paper read to the Royal Geographical Society on April 18, by Mr. S. T. A. Mirrlees, new light is thrown on the winter climate of the interior of southern Greenland. Mr. Mirrlees pointed out that nearly all our knowledge of the climate of this region is based upon observations made on summer sledge journeys, supplemented by the observations made throughout the year at the various coast stations of the Danish Meteorological Service. Greenland lies to the north of the region of the world's most persistent cyclonic activity, but-if we accept as accurate the distribution of high and low pressure shown on the daily charts of the British Meteorological Office and similar older publications, such as those of the Danish Admiralty-is at all seasons liable to be invaded by the cyclonic depressions of the North Atlantic.

In a series of observations made every three hours between Sept. 8, 1930, and April 26, 1931, at about lat. $67^{\circ}$ N., long. $42^{\circ}$ W., at a height of about
$8250 \mathrm{ft}$. , by the British Arctic Air Route Expedition, his hypothesis is confirmed. The direct influence of the Atlantic depressions on the weather was found normally to be small, as is shown by the low figures for the monthly mean proportion of the sky covered by cloud, which varied from five-tenths in September to three-tenths in February. The mean for the whole period must therefore have been roughly comparable with the normal for the French Riviera. But there were some stormy periods and even gales, and the strongest winds showed no tendency to be more prevalent from the prevailing northerly direction of the wind than from other quarters; moreover, the characteristic changes of wind, pressure, and weather caused by the passage of the centre of a depression directly over or to the north of the place of observation were observed.

Very low temperatures had been expected, and were not wanting, for a reading of $-59^{\circ} \mathrm{F}$. was

No. 3276 , Vor. 130 ] 